\title{
EFFECT OF POSTHARVEST TREATMENTS WITH SALICYLIC ACID AND CHITO-CARE ON NAVEL ORANGE FRUITS QUALITY AND STORABILITY COMPARED WITH THE COMMERCIAL POSTHARVEST FUNGICIDE TREATMENT
}

Mohamed, M. A. A. ${ }^{*}$; H. G. El-Mehrat ${ }^{\star \star}$ and A. S. E. Salem ${ }^{\star \star}$

* Fruit Handling Dep., Hort. Res. Inst., Agric. Res. Center, Giza, Egypt.

** Central Lab. of Organic Agriculture. Agric. Res. Center, Giza, Egypt.

\begin{abstract}
This study was carried out during two successive seasons 2010-2011 and 2011-2012 on Navel orange at fruit handling department, horticulture research institute, Giza, Egypt. Fruits were harvested at maturity stage from a private orchard in El-Fayoum governorate, Egypt. At the laboratory, fruits were dipped in 200 or 300 ppm of Salicylic acid or 10000 or 20000 ppm of Chito-care or the combination between the two doses from each compound. Other fruits were dipped in $1500 \mathrm{ppm}$ of Imazalil, the commercial postharvest treatment to be used as control. Fruits were stored at $10^{\circ} \mathrm{C}$ and $85-90$ R.H. for up to six months. Fruits were examined monthly intervals to determine the effect of these treatments on fruit physical and chemical properties. Results cleared that, weight loss and decay percentage, total soluble solids and total soluble sugars contents of orange fruits increased while fruit firmness, total acidity and vitamin C contents decreased gradually and significantly with the increasing of storage periods. Peel fruit color changed directly from green yellow to yellow with the increasing of storage periods. Postharvest treatments with either Salicylic acid or Chito-care significantly decreased weight loss, decay incidence, fruit firmness deterioration rate, the change of peel color, the decreasing rate of total acidity and vitamin C contents of orange fruits compared with the commercial postharvest treatment during storage. On the other side, there were no clear trends concerning the effect of these treatments on total soluble solids and total soluble sugars contents of orange fruits during storage. Moreover, the higher doses either alone or in combination with the other compound had the priority. In briefly we can conclude that, orange fruits postharvest treatments with any of the examined compounds with the higher dose to reduce postharvest decay incidence during transportation process or cold storage could be a successfull alternative to reduce the using of fungicide on orange fruits and to reduce its bad effects on consumer healthy and the environment.
\end{abstract}

Keywords: Citrus - Navel Orange - Postharvest - Salicylic acid - Chito-care.

\section{INTRODUCTION}

Orange industry is an important for Egyptian National income. Orange Planted area in Egypt reached 57589 feddans in 2011, while produced area reached 55853 feddans producing 1152965 tons of orange fruits according to the statistics of Ministry of Agriculture, Egypt (2012). Although orange occupies the greatest planted area among all citrus grown fruit area in Egypt, the exportation of fresh orange fruits to foreign markets are still limited compared with the produced quantity. Therefore, any effort 
directed towards maintaining fruit quality and reducing postharvest losses are importance for increasing our National income. There is a worldwide trend to explore new alternatives that control postharvest pathogenic diseases, giving priority to methods that reduce disease incidence and avoid negative and side effects on human health as a result of the excessive application of synthetic fungicides. In addition, the emergence of fungicide-resistant strains of microorganisms and the continuous rigorous regulation of fungicide use and disposal has reduced the possibility to conceive control strategies based on chemicals (Johnson and Sangchote, 1994). Salicylic acid and its derivatives used widely to enhance fruits postharvest life by controlling their firmness. Salicylic acid has been documented to enhance flesh firmness of harvested peaches during storage (Yan et al. 1998; Li and Han, 1999; Wang et al. 2006), and banana fruits during ripening (Srivastava \& Dwivedi,2000). Postharvest application with salicylic acid significantly reduced decay incidence of sweet cherry fruits during storage compared with that of the untreated fruits (Yao and Tian, 2005). Also, reduced the quality loss in peaches (Wang et al.2007). Solaimani et al.(2009) found that, Application of exogenous methyl salicylate vapor on kiwifruits led to prevent the softening process of fruit flesh, kept ascorbic acid content and firmness during 5 months storage. Kazemi, et al.(2011) illustrated that, apple fruit weight loss significantly decreased in all salicylic acid concentrations, $(0,1.5,3 \mathrm{mM})$ for 5 $\mathrm{min}$, in comparison with control. Also, the results showed that fruits treated with salicylic acid solution for 5 minutes had higher firmness, total acidity (TA), and lower total soluble solids (TSS) than fruits that treated in control. Barakat, et al. (2012) found that, weight loss and decay incidence of orange fruits and total soluble solids contents of orange fruit juice were increased gradually and significantly with the increasing of storage period. On contrary total acidity and ascorbic acid contents of orange fruit juice were decreased with the increasing of storage period. They also added that, orange fruits firmness decreased gradually and significantly while color changed directly from green yellow to yellow with the prolongation of storage periods. Tareen et al.(2012) illustrated that, postharvest treatments with salicylic acid at 2.0

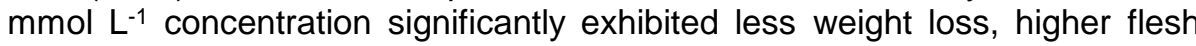
firmness, increased TSS, higher TA and ascorbic acid contents, higher peel luminosity and decreased $a^{*}$ values of peach fruits compared with other treatments including control. Du et al.(1997) mentioned that Chito-care significantly decreased post-harvested spoilage of peach, 'Housui' pear and kiwi fruit. They also added that, Chito-care-coated peach and 'Shinko' pear were markedly firmer and less mature at the end of storage. Kittur et al. (2001) demonstrated that, lower reducing sugars than the untreated fruits were found in banana fruits treated with Chito-care at the end of the storage period. Romanazzi et al. (2002) reported that, decay incidence of Chito-care coated grapes was less than that of the uncoated grapes. Chien et al.(2007) mentioned that, weight losses of citrus fruit increased continuously during storage. They also added that, weight loss associated with coating treatments was slower than that of the uncoated citrus fruit compared with the control fruits. The same trend was recorded by Zhou et al. (2008) on coated pear 
fruits. Chien et al.(2007) mentioned that, decay incidence of citrus fruit increased continuously during storage. They also added that, decay incidence associated with coating treatment was less than that of the uncoated citrus fruit compared with the control fruits. Wang et al.(2007) reported that, postharvest treatments with $2 \%$ Chito-care significantly reduced weight loss percentage, decay incidence, colour change and total acidity contents of mango fruits during storage compared with untreated fruits. On the other hand, these treatments significantly increased total soluble solids contents of mango fruits during storage compared with untreated fruits. The same results were mentioned by Zhu et al.(2008) on mango fruits. Moreover, they added that, these treatments significantly increased ascorbic acid (V. C.) contents of mango fruits during storage compared with untreated fruits. The aim of this research is to study the influence of salicylic acid and Chito-care to maintain "Navel" Orange fruits quality and to reduce postharvest losses during cold storage compared with the commercial postharvest fungicide treatment.

\section{MATERIALS AND METHODS}

This study was carried out during two successive seasons 20102011 and 2011-2012 on Navel orange.

Fruit Material, Post harvest Treatments, and Storage Regime:

Navel orange fruits (Citrus sinensis Osbeck) were harvested at maturity stage according to Abd El-Hafeez (1998) in the second week of December during the two seasons from a private orchard in El-Fayoum governorate, Egypt. Fruits were directly transported to the laboratory at Fruit Handling Department, Horticulture Research Institute, Agriculture Research Center, Giza, Egypt. Fruits were washed, air dried and subjected to the following treatments by dipping for 5 minutes: -

1- Treated with $1500 \mathrm{ppm}$ of Imazalil, the commercial postharvest as control (A), 2 \& 3- Treated with 200 or 300 ppm of Salicylic acid (S1- S2), 4 \& 5- Treated with 10000 or $20000 \mathrm{ppm}$ of Chito-care (K1-K2), 6- Treated with 300 ppm Salicylic acid with 20000 Chito-care (S2K2), 7Treated with $200 \mathrm{ppm}$ Salicylic acid with 10000 Chito-care (S1K1), 8- Treated with $200 \mathrm{ppm}$ of Salicylic acid with 20000 ppm Chito-care (S1K2), 9- Treated with 300 ppm Salicylic acid with 10000 ppm Chito-care (S2K1).

Then all fruits were air dried again, waxed and packed in carton boxes in one layer and stored at $10^{\circ} \mathrm{C}$ and $85-90$ R.H. Each treatment had 6 boxes each box had 20 fruits, three boxes were used in order to determine weight loss and decay percentage while the other boxes were used in order to determine the other physical and chemical properties. 


\section{Measurements:-}

At one month intervals, Samples (3 replicates each had 6 fruits) of each treatment were taken for the following some physical and chemical properties determinations.

\section{1- Methods of determining physical properties:}

1.1- Weight loss percentage: it was calculated as a percentage of the average loss in fruit weight for different treatments, separately, at examined date in relation to the initial weight at the beginning of the experiment.

1.2- Decay percentage: Fruits affected with either pathological or physiological disorders were counted and calculated as percentage.

1.3- Fruits Firmness: These values were determined using Lfra Texture Analyser in $5 \mathrm{~mm}$ depth and $0.2 \mathrm{~mm} /$ second speed, for measuring firmness of Orange, These values were determined by taking the firmness value of six fruits by two sides and the average of the fruit firmness was calculated as (g/sq. cm).

1.4- Peel color: These values were estimated in six fruits by using hunter colorimeter model DP9000. (Hue angel) were determined and the values were calculated according to Mc Gjuire (1992).

2- Chemical properties:

2.1- Total soluble solids (T.S.S.) contents: T.S.S. contents of fruits were determined by abbe-digital refractometer.

2.2- Total acidity percentage: Total acidity content was determined according to A.O.A.C. (1990).

2.4- Ascorbic acid content (Vitamin C): Ascorbic acid was determined according to (Lucas, 1944).

2.5- Total soluble sugars: It was calculated as described by Association of Official Agriculture Chemistry (A.O.A.C, 1990).

Statistical analysis: the obtained data were statistically analyzed as complete randomized factorial design. Means were compared by Duncan's multiple range tests at the level of $5 \%$ probability according to Snedecor and Cochran (1980).

\section{RESULTS AND DISCUSSION}

\section{1- Weight loss and Decay percentage:-}

Data illustrated in tables $(1 \& 2)$ indicated that, weight loss and decay percentage of orange fruits were increased gradually and significantly with the increasing of storage periods during the two seasons in this work. Data also cleared that, all the examined postharvest treatments significantly decreased weight loss and decay incidence of orange fruits compared with the commercial postharvest treatment during the two seasons in this work. Moreover, data also illustrated that, postharvest treatment with the high concentration of Chito-care (20000 ppm) followed by the combination between the high concentration of Chito-care (20000 ppm) and Salicylic acid $(300 \mathrm{ppm})$ during the first season and the high concentration of Salicylic acid (300 ppm) during the second season were the most effective treatments in 
this aspect. On the other hand, orange fruits treated with the commercial postharvest treatment had the highest weight loss and decay percentage during the two seasons in this work.

These results are in agreement with those obtained by Chien et al. (2007) and Barakat, et al. (2012), they illustrated that, weight loss and decay percentage of citrus fruits were increased gradually and significantly with the increasing of storage periods. Also these results are in harmony with those obtained by Yao and Tian, (2005) on sweet cherry fruits, Wang et al.(2007) on peach fruits, Kazemi, et al.(2011) on apple fruits and Tareen et al.(2012) on peach fruits. They demonstrated that, post-harvest application with salicylic acid significantly reduced decay and weight loss incidence of fruits during storage compared with that of the untreated fruits. Moreover, these results are in line with those demonstrated by Du et al.(1997) on peach, 'Housui' pear and kiwi fruits, Romanazzi et al.(2002) on grape fruits, Chien et al.(2007) on citrus fruits, Wang et al.(2007) on mango fruits, Zhou et al.(2008) on pear fruits, and Zhu et al.(2008) on mango fruits. They mentioned that, postharvest treatments with Chito-care significantly reduced decay and weight loss incidence of fruits.

Table No (1):- Effect of Postharvest Treatments with Salicylic acid and Chito-care on Weight Loss Percentage of Navel Orange Fruits during cold storage.

\begin{tabular}{|c|c|c|c|c|c|c|c|c|c|c|}
\hline \multirow{2}{*}{$\begin{array}{c}\text { Storage } \\
\text { period }\end{array}$} & \multicolumn{10}{|c|}{ Postharvest treatments } \\
\hline & $\mathbf{A}$ & S1 & S2 & K1 & K2 & S2K2 & S1K1 & S1K2 & S2K1 & Means \\
\hline \multicolumn{11}{|c|}{ First season (2009-2010) } \\
\hline 0 & 0 & 0 & 0 & 0 & 0 & 0 & 0 & 0 & 0 & 0 \\
\hline 1 & 3.26 & 3.17 & 1.35 & 2.85 & 0.49 & 2.57 & 3.96 & 2.69 & 3.1 & 2.604 \\
\hline 2 & 7.77 & 4.89 & 5.15 & 4.89 & 2.35 & 4.29 & 5.94 & 6.92 & 4.5 & 5.189 \\
\hline 3 & 12.8 & 8.65 & 13.44 & 8.83 & 3.58 & 7.05 & 11.38 & 10 & 5.2 & 8.989 \\
\hline 4 & 17.2 & 17.86 & 20.05 & 13.04 & 5.68 & 9.2 & 15.84 & 16.15 & 6.1 & 13.45 \\
\hline 5 & 23 & 18.27 & 22.22 & 18.47 & 8.53 & 11.78 & 20.54 & 21.15 & 8.1 & 16.9 \\
\hline 6 & 27.6 & 25.93 & 25.47 & 24.45 & 13.22 & 15.58 & 25.74 & 26.92 & 12.5 & 21.93 \\
\hline Means & 13.1 & 11.25 & 12.53 & 10.36 & 4.836 & 7.21 & 11.91 & 11.98 & 5.643 & \\
\hline \multicolumn{11}{|c|}{ Second season (2010-2011) } \\
\hline 0 & 0 & 0 & 0 & 0 & 0 & 0 & 0 & 0 & 0 & 0 \\
\hline 1 & 4.81 & 3.69 & 3.44 & 4.33 & 3.18 & 5.31 & 4.98 & 4.45 & 4.12 & 4.257 \\
\hline 2 & 6.84 & 6.41 & 6.18 & 7.57 & 5.22 & 9.66 & 8.63 & 6.43 & 8.51 & 7.272 \\
\hline 3 & 11.64 & 9.64 & 8.5 & 13.94 & 8.28 & 12.47 & 17.49 & 13.98 & 12.17 & 12.01 \\
\hline 4 & 12.1 & 11.95 & 10.8 & 15.83 & 10.57 & 13.21 & 19.37 & 15.06 & 15.45 & 13.82 \\
\hline 5 & 17.6 & 15.43 & 13.55 & 19.62 & 12.22 & 14.43 & 22.25 & 19.71 & 22.35 & 17.46 \\
\hline 6 & 23.68 & 18.23 & 15.81 & 22.94 & 15.2 & 16.63 & 24.6 & 22.15 & 23.88 & 20.35 \\
\hline Means & 10.95 & 9.336 & 8.326 & 12.03 & 7.81 & 10.24 & 13.9 & 11.68 & 12.35 & \\
\hline \multicolumn{11}{|c|}{ LSD Values at $5 \%$ level } \\
\hline \multicolumn{4}{|c|}{ Studied factors } & \multicolumn{2}{|c|}{ Treat. } & \multicolumn{2}{|c|}{ St. Per } & \multicolumn{3}{|c|}{ Interaction } \\
\hline \multicolumn{4}{|c|}{ Values, First season } & \multicolumn{2}{|c|}{0.015} & \multicolumn{2}{|c|}{0.0132} & \multicolumn{3}{|c|}{0.0396} \\
\hline \multicolumn{4}{|c|}{ Values, Second season } & \multicolumn{2}{|c|}{0.014} & \multicolumn{2}{|c|}{0.012} & \multicolumn{3}{|c|}{0.036} \\
\hline
\end{tabular}

Notes:- A= Imazalil, S= Salicylic acid 200 ppm, S2= Salicylic acid 300 ppm, K1= Chito-care 10000 ppm, K2= Chito-care 20000 ppm, Storage period by months. 
Mohamed, M. A. A. et al.

Table No (2):- Effect of Postharvest Treatments with Salicylic acid and Chito-care on Decay Percentage of Navel Orange Fruits during cold storage.

\begin{tabular}{|l|c|c|c|c|c|c|c|c|c|c|c|}
\hline \multirow{2}{*}{$\begin{array}{c}\text { Storage } \\
\text { period }\end{array}$} & \multicolumn{10}{c|}{ Postharvest treatments } \\
\cline { 2 - 12 } & $\mathbf{A}$ & S1 & S2 & \multicolumn{1}{c|}{ K1 } & K2 & S2K2 & S1K1 & S1K2 & S2K1 & Means \\
\hline 0 & 0 & 0 & 0 & 0 & 0 & 0 & 0 & 0 & 0 & 0 \\
\hline 1 & 2.28 & 0 & 0 & 0 & 0 & 0 & 0 & 0 & 0 & 0.253 \\
\hline 2 & 4.17 & 4.17 & 0 & 0 & 0 & 2.08 & 4.16 & 6.25 & 4.16 & 2.777 \\
\hline 3 & 8.33 & 6.25 & 0 & 8.33 & 0 & 6.25 & 8.33 & 8.33 & 6.25 & 5.786 \\
\hline 4 & 10.4 & 8.33 & 4.16 & 10.41 & 2.08 & 8.33 & 14.58 & 12.5 & 10.41 & 9.023 \\
\hline 5 & 14.6 & 12.5 & 6.25 & 16.66 & 6.25 & 10.41 & 16.66 & 16.66 & 14.58 & 12.73 \\
\hline 6 & 25 & 18.75 & 16.66 & 22.91 & 18.75 & 25 & 27.08 & 25 & 25 & 22.68 \\
\hline Means & 9.25 & 7.143 & 3.867 & 8.33 & 3.869 & 7.439 & 10.12 & 9.82 & 8.629 & \\
\hline
\end{tabular}

\begin{tabular}{|l|c|c|c|c|c|c|c|c|c|c|}
\hline 0 & 0 & 0 & 0 & 0 & 0 & 0 & 0 & 0 & 0 & 0 \\
\hline 1 & 0 & 0 & 0 & 0 & 0 & 0 & 0 & 0 & 0 & 0 \\
\hline 2 & 0 & 0 & 0 & 0 & 0 & 0 & 0 & 0 & 0 & 0 \\
\hline 3 & 2.08 & 0 & 0 & 0 & 0 & 0 & 0 & 0 & 0 & 0.231 \\
\hline 4 & 4.17 & 4.17 & 2.08 & 8.33 & 0 & 0 & 4.16 & 6.25 & 4.16 & 3.702 \\
\hline 5 & 14.58 & 8.33 & 6.25 & 10.41 & 2.08 & 6.25 & 12.5 & 10.41 & 8.33 & 8.793 \\
\hline 6 & 22.91 & 16.66 & 12.5 & 20.83 & 10.41 & 14.58 & 16.66 & 20.83 & 18.75 & 17.13 \\
\hline \begin{tabular}{|l|l|}
$|l|$ \\
\hline
\end{tabular} & 6.249 & 4.166 & 2.976 & 5.653 & 1.784 & 2.976 & 4.76 & 5.356 & 4.463 & \\
\hline
\end{tabular}

Notes:- A= Imazalil, S= Salicylic acid 200 ppm, S2= Salicylic acid 300 ppm, K1= Chito-care 10000 ppm, K2= Chito-care 20000 ppm, Storage period by months.

\section{2- Fruits Firmness:}

Data presented in table (3) indicated that, orange fruit firmness was decreased gradually and significantly with the increasing of storage period during the two seasons in this work. Data also cleared that, all the postharvest treatments significantly, with some exceptions, two treatments during the first season and one treatment during the second season, reduced the deterioration rate of orange fruit firmness compared with the commercial postharvest treatment during the two seasons in this work. However, there was no clear trend concerning these effects, while fruits treated with the low dose of salicylic acid followed by those treated with the high doses of salicylic acid and chito-care high doses had the highest fruit firmness values during the first season. On the other side, fruits treated with the combination between the high dose of salicylic acid and the low dose of chito-care followed by those treated with the combination between the low dose of salicylic acid and the high dose chito-care had the highest fruit firmness values during the second season. On the other hand, orange fruits treated with the commercial postharvest treatment had the lowest fruit firmness values during the two seasons in this work.

These results are in line with those mentioned by Barakat, et al. (2012) who demonstrated that, orange fruits firmness was decreased gradually and significantly with the prolongation of storage periods. Also 
these results are in harmony with those demonstrated by Yan et al.(1998) on peach fruits, Li and Han,(1999) on peach fruits, Srivastava \& Dwivedi,(2000) on banana fruits, Wang et al.(2006 \& 2007) on peach fruits, Solaimani et al.(2009), on kiwifruit fruits, Kazemi, et al.(2011) on apple fruits and Tareen et al.(2012) on peach fruits. They reported that, postharvest treatments with salicylic acid significantly exhibited higher flesh firmness of fruits during storage.

3 - Peel fruit color:

Data presented in table (4) indicated that, peel fruit color, (represented as hue angle value) was changed directly from green yellow to yellow with the increasing of storage periods during the two seasons in this work. Also these results showed that, all the postharvest treatments significantly reduced the change rate of peel color compared with that treated with the commercial postharvest treatment during the two seasons in this work. Moreover, data also cleared that, orange fruits treated with the combination between the high dose of salicylic acid and chito-care followed by those treated with the high dose of salicylic acid had the less peel color change rate during the two seasons in this work. On contrast, orange fruits treated with the commercial postharvest treatment had the highest peel color change rate.

Table No (3):- Effect of Postharvest Treatments with Salicylic acid and Chito-care on Firmness $\left(\mathrm{g} / \mathrm{c}^{2}\right)$ of Navel Orange Fruits during cold storage.

\begin{tabular}{|c|c|c|c|c|c|c|c|c|c|c|}
\hline \multirow{2}{*}{\begin{tabular}{|c|}
$\begin{array}{c}\text { Storage } \\
\text { period }\end{array}$ \\
\end{tabular}} & \multicolumn{10}{|c|}{ Postharvest treatments } \\
\hline & $\overline{\mathbf{A}}$ & S1 & S2 & K1 & K2 & S2K2 & S1K1 & S1K2 & S2K1 & Means \\
\hline \multicolumn{11}{|c|}{ First season (2009-2010) } \\
\hline 0 & 293 & 293 & 293 & 293 & 293 & 293 & 293 & 293 & 293 & 293 \\
\hline 1 & 222 & 258 & 252 & 222 & 261 & 244 & 214 & 219 & 220 & 235 \\
\hline 2 & 219 & 235 & 225 & 220 & 218 & 241 & 211 & 216 & 219 & 223 \\
\hline 3 & 190 & 221 & 223 & 212 & 216 & 218 & 229 & 211 & 213 & 215 \\
\hline 4 & 142 & 139 & 152 & 146 & 153 & 143 & 139 & 147 & 153 & 147 \\
\hline 5 & 125 & 130 & 140 & 119 & 137 & 129 & 127 & 130 & 132 & 130 \\
\hline 6 & 116 & 111 & 127 & 110 & 118 & 120 & 115 & 121 & 123 & 118 \\
\hline Means & 187 & 189 & 202 & 188 & 199 & 198 & 190 & 191 & 193 & \\
\hline \multicolumn{11}{|c|}{ Second season (2010-2011) } \\
\hline 0 & 287.7 & 287.7 & 287.7 & 287.7 & 287.7 & 287.7 & 287.7 & 287.7 & 287.7 & 287.7 \\
\hline 1 & 259.3 & 262.3 & 261 & 262.7 & 268.3 & 251.3 & 254.7 & 260 & 281 & 262.3 \\
\hline 2 & 244.7 & 238 & 251 & 230 & 244 & 239.3 & 243.3 & 244.3 & 247.7 & 242.5 \\
\hline 3 & 224 & 223.3 & 221.7 & 225.7 & 212.3 & 211 & 215.7 & 216 & 227.3 & 219.7 \\
\hline 4 & 138 & 143.7 & 184 & 148 & 143 & 141.7 & 149.7 & 145 & 174 & 151.9 \\
\hline 5 & 108.3 & 123.7 & 132.7 & 123 & 122.3 & 127.7 & 125.7 & 102.7 & 132 & 122 \\
\hline 6 & 77.66 & 88.33 & 93.33 & 96 & 105 & 111 & 109 & 94.33 & 105.3 & 97.78 \\
\hline Means & 191.4 & 195.3 & 204.5 & 196.1 & 197.5 & 195.7 & 197.9 & 192.9 & 207.9 & \\
\hline \multicolumn{11}{|c|}{ LSD Values at $5 \%$ level } \\
\hline \multicolumn{4}{|c|}{ Studied factors } & \multicolumn{2}{|c|}{ Treat. } & \multicolumn{2}{|c|}{ St. Per } & \multicolumn{3}{|c|}{ Interaction } \\
\hline \multicolumn{4}{|c|}{ Values, First season } & \multicolumn{2}{|c|}{11.5} & \multicolumn{2}{|c|}{10.14} & \multicolumn{3}{|c|}{30.42} \\
\hline \multicolumn{4}{|c|}{ Values, Second season } & \multicolumn{2}{|c|}{5.18} & \multicolumn{2}{|c|}{4.57} & \multicolumn{3}{|c|}{13.71} \\
\hline
\end{tabular}

Notes:- A= Imazalil, S= Salicylic acid 200 ppm, S2= Salicylic acid 300 ppm, K1= Chito-care 10000 ppm, K2= Chito-care 20000 ppm, Storage period by months. 
Table No (4):- Effect of Postharvest Treatments with Salicylic acid and Chito-care on Peel Colour of Navel Orange Fruits during cold storage.

\begin{tabular}{|c|c|c|c|c|c|c|c|c|c|c|}
\hline \multirow{2}{*}{$\begin{array}{c}\text { Storage } \\
\text { period }\end{array}$} & \multicolumn{10}{|c|}{ Postharvest treatments } \\
\hline & $\mathbf{A}$ & S1 & S2 & $\mathrm{K} 1$ & $\mathrm{~K} 2$ & S2K2 & S1K1 & S1K2 & S2K1 & Means \\
\hline \multicolumn{11}{|c|}{ First season } \\
\hline 0 & 70.1 & 70.1 & 70.1 & 70.1 & 70.1 & 70.1 & 70.1 & 70.1 & 70.1 & 70.1 \\
\hline 1 & 66 & 66.5 & 70 & 69.8 & 67.2 & 69.9 & 68.2 & 69 & 69.4 & 68.45 \\
\hline 2 & 63.2 & 61.3 & 66 & 65 & 65.4 & 67 & 66.2 & 63 & 64 & 64.56 \\
\hline 3 & 62.2 & 61 & 65 & 64.6 & 63.7 & 65 & 64 & 61.8 & 62.6 & 63.32 \\
\hline 4 & 60.2 & 60 & 63 & 62 & 63 & 63.6 & 61 & 60.9 & 61.8 & 61.72 \\
\hline 5 & 60 & 60.2 & 62.8 & 61.2 & 62.2 & 62.4 & 60 & 61 & 60.8 & 61.18 \\
\hline 6 & 59.8 & 64 & 61.9 & 62.4 & 60.8 & 62 & 60.4 & 60.3 & 61.8 & 61.49 \\
\hline Means & 63.1 & 63.3 & 65.54 & 65.01 & 64.63 & 65.71 & 64.27 & 63.73 & 64.36 & \\
\hline \multicolumn{11}{|c|}{ Second season (2010-2011) } \\
\hline 0 & 68.22 & 68.22 & 68.22 & 68.22 & 68.22 & 68.22 & 68.22 & 68.22 & 68.22 & 68.22 \\
\hline 1 & 64.13 & 64.62 & 71.92 & 71.01 & 68.92 & 72.38 & 63.43 & 69.28 & 68.26 & 68.22 \\
\hline 2 & 61.29 & 60.4 & 64.78 & 63.7 & 64.57 & 63.4 & 63.9 & 62.88 & 62.79 & 63.08 \\
\hline 3 & 59 & 60.89 & 63.02 & 61.13 & 61.69 & 63.14 & 61.33 & 62 & 64 & 61.8 \\
\hline 4 & 58 & 63 & 59 & 61 & 61 & 63 & 59 & 61 & 63 & 60.89 \\
\hline 5 & 59 & 64 & 61 & 60 & 60 & 61 & 58 & 60.3 & 61.69 & 60.55 \\
\hline 6 & 59.22 & 66.19 & 62.43 & 63.45 & 61.69 & 59.37 & 58.74 & 59.69 & 60.37 & 61.24 \\
\hline Means & 61.27 & 63.9 & 64.34 & 64.07 & 63.73 & 64.36 & 61.8 & 63.34 & 64.05 & \\
\hline \multicolumn{11}{|c|}{ LSD Values at $5 \%$ level } \\
\hline \multicolumn{4}{|c|}{ Studied factors } & \multicolumn{2}{|c|}{ Treat. } & \multicolumn{2}{|c|}{ St. Per } & \multicolumn{3}{|c|}{ Interaction } \\
\hline \multicolumn{4}{|c|}{ Values, First season } & \multicolumn{2}{|c|}{0.0086} & \multicolumn{2}{|c|}{0.0076} & \multicolumn{3}{|c|}{0.0228} \\
\hline \multicolumn{4}{|c|}{ Values, Second season } & \multicolumn{2}{|c|}{0.0105} & \multicolumn{2}{|c|}{0.0093} & \multicolumn{3}{|c|}{0.0279} \\
\hline
\end{tabular}

Notes:- A= Imazalil, S= Salicylic acid 200 ppm, S2= Salicylic acid 300 ppm, K1= Chito-care 10000 ppm, K2= Chito-care 20000 ppm, Storage period by months.

These results are in harmony with those obtained by Barakat, et al.(2012) who illustrated that, orange fruits color gradually changed from green yellow to yellow with the increasing of storage periods. Also these results are in harmony with those mentioned by Tareen et al.(2012) who illustrated that, postharvest treatments with salicylic acid significantly decreased $\mathrm{a}^{*}$ values of peach fruits compared with other treatments including control. On the other side, these results are in agreements with those found by Wang et al.(2007) and Zhu et al.(2008) they reported that, postharvest treatments with Chito-care significantly reduced color change rate of mango fruits during storage compared with untreated fruits.

4- Total Soluble Solids (T.S.S.), Total Acidity (TA), Vitamin C and Total Soluble Sugars contents:-

Data presented in tables $(5,6,7$ and 8$)$ showed that, total soluble solids and total soluble sugars contents of orange fruits were increased gradually and significantly with the increasing of storage periods during the two seasons in this work. On contrary, total acidity and vitamin C contents of orange fruits were decreased gradually and significantly with the increasing of storage periods during the two seasons in this work. Data also cleared that, all the examined postharvest treatments had effect on total soluble solids, total acidity, vitamin $\mathrm{C}$ and total soluble sugars contents of stored orange fruits during the first season in this work. While in the second season this 
trend was clear in case of total soluble solids and total soluble sugars contents, on contrast, these treatments significantly reduced the decreasing rate of total acidity and vitamin $\mathrm{C}$ contents of orange during storage compared with those treated with the commercial postharvest treatment.

These results agree with those found by Barakat, et al.(2012) who demonstrated that, total soluble solids contents of orange fruits increased while total acidity and vitamin $\mathrm{C}$ contents of orange fruits decreased gradually and significantly with the increasing of storage periods. Also these results partially are in harmony with those demonstrated by Kazemi, et al.(2011) and Tareen et al.(2012) they demonstrated that, peach fruits postharvest treated with salicylic acid had significantly higher TA and ascorbic acid contents compared with other treatments including control. Moreover, these results agree with those obtained by Du et al.(1997) who mentioned that, Chito-care significantly increased TA contents of peach and 'Shinko' pear fruits at the end of storage.

Table No (5):- Effect of Postharvest Treatments with Salicylic acid and Chito-care on TSS Contents of Navel Orange Fruits during cold storage.

\begin{tabular}{|c|c|c|c|c|c|c|c|c|c|c|}
\hline \multirow{2}{*}{$\begin{array}{c}\text { Storage } \\
\text { period }\end{array}$} & \multicolumn{10}{|c|}{ Postharvest treatments } \\
\hline & $\mathbf{A}$ & S1 & S2 & K1 & K2 & S2K2 & S1K1 & S1K2 & S2K1 & Means \\
\hline \multicolumn{11}{|c|}{ First season (2009-2010) } \\
\hline 0 & 10.1 & 10.13 & 10.13 & 10.13 & 10.13 & 10.13 & 10.13 & 10.13 & 10.13 & 10.13 \\
\hline 1 & 11.3 & 11.1 & 11.7 & 11.2 & 11.53 & 11.13 & 10.87 & 11 & 11.3 & 11.23 \\
\hline 2 & 12.3 & 11.63 & 11.9 & 12.06 & 11.63 & 12 & 11.67 & 11.83 & 11.8 & 11.87 \\
\hline 3 & 12.3 & 12 & 12.16 & 12.23 & 11.47 & 12.16 & 12.36 & 12.13 & 11.9 & 12.08 \\
\hline 4 & 12.3 & 12.2 & 12.36 & 12.53 & 11.86 & 12.5 & 12.57 & 12.4 & 12.5 & 12.36 \\
\hline 5 & 12.1 & 12.47 & 12.7 & 12.67 & 11.93 & 12.7 & 12.33 & 12.03 & 12.7 & 12.41 \\
\hline 6 & 11.8 & 12.13 & 12.53 & 12.83 & 12.83 & 12.23 & 12.13 & 12.73 & 12.1 & 12.37 \\
\hline Means & 11.8 & 11.67 & 11.93 & 11.95 & 11.63 & 11.84 & 11.72 & 11.75 & 11.78 & \\
\hline \multicolumn{11}{|c|}{ Second season (2010-2011) } \\
\hline 0 & 10.2 & 10.2 & 10.2 & 10.2 & 10.2 & 10.2 & 10.2 & 10.2 & 10.2 & 10.2 \\
\hline 1 & 11.9 & 11.3 & 10.8 & 10.4 & 11.4 & 10.6 & 10.9 & 10.7 & 10.8 & 10.98 \\
\hline 2 & 12.3 & 12.4 & 12.1 & 11.2 & 12 & 11.7 & 11.4 & 11.3 & 12 & 11.82 \\
\hline 3 & 12.56 & 12.8 & 12.5 & 12.2 & 12.1 & 12.4 & 12.3 & 12.5 & 12.2 & 12.4 \\
\hline 4 & 12.1 & 12.5 & 12.9 & 12.8 & 12.6 & 12.2 & 12.3 & 11.4 & 12.5 & 12.37 \\
\hline 5 & 11.2 & 11.6 & 11.8 & 11.4 & 11.1 & 11.2 & 10.9 & 11 & 11.2 & 11.27 \\
\hline 6 & 10.16 & 10.6 & 11.13 & 11.03 & 10.6 & 10.53 & 10.3 & 10.23 & 10.53 & 10.57 \\
\hline Means & 11.49 & 11.63 & 11.63 & 11.32 & 11.43 & 11.26 & 11.19 & 11.05 & 11.35 & \\
\hline \multicolumn{11}{|c|}{ LSD Values at $5 \%$ level } \\
\hline \multicolumn{4}{|c|}{ Studied factors } & \multicolumn{2}{|c|}{ Treat. } & \multicolumn{2}{|c|}{ St. Per } & \multicolumn{3}{|c|}{ Interaction } \\
\hline \multicolumn{4}{|c|}{ Values, First season } & \multicolumn{2}{|c|}{ N.S } & \multicolumn{2}{|c|}{0.48} & \multicolumn{3}{|c|}{ N.S } \\
\hline \multicolumn{4}{|c|}{ Values, Second season } & \multicolumn{2}{|c|}{ N.S } & \multicolumn{2}{|c|}{0.41} & \multicolumn{3}{|c|}{ N.S } \\
\hline
\end{tabular}

Notes:- A= Imazalil, S= Salicylic acid 200 ppm, S2= Salicylic acid 300 ppm, K1= Chito-care 10000 ppm, K2= Chito-care 20000 ppm, Storage period by months.

On contrast, these results disagree with those mentioned by Kazemi, et al.(2011) who illustrated that, apple fruits postharvest treated with 
salicylic acid solution for 5 minutes had lower TSS than untreated fruits. Also, disagree with Tareen et al.(2012), who suggested that, postharvest treatments with salicylic acid significantly increased SSC contents of peach fruits during storage compared with control fruits. Also, these resultes disagree with those obtained by Du et al.(1997) who mentioned that, Chitocare significantly decreased TSS contents of peach and 'Shinko' pear fruits at the end of storage. Moreover, these resultes disagree with those mentioned by Wang et al.(2007) and Zhu et al.(2008) they obtained that, Chito-care significantly increased TSS and decreased TA contents of Mango fruits during storage compared with untreated fruits. Morover, these results disagree with those found by Kittur et al. (2001) demonstrated that, lower reducing sugars than the untreated fruits were found in banana fruits treated with Chito-care at the end of the storage period.

Table No (6):- Effect of Postharvest Treatments with Salicylic acid and Chito-care on Total Acidity Contents of Navel Orange Fruits during cold storage.

\begin{tabular}{|c|c|c|c|c|c|c|c|c|c|c|}
\hline \multirow{2}{*}{$\begin{array}{l}\text { Storage } \\
\text { period }\end{array}$} & \multicolumn{10}{|c|}{ Postharvest treatments } \\
\hline & $\mathbf{A}$ & S1 & S2 & K1 & K2 & S2K2 & S1K1 & S1K2 & S2K1 & Means \\
\hline \multicolumn{11}{|c|}{ First season } \\
\hline 0 & 1.09 & 1.09 & 1.09 & 1.09 & 1.09 & 1.09 & 1.09 & 1.09 & 1.09 & 1.09 \\
\hline 1 & 0.98 & 1.02 & 1.08 & 1.12 & 1.04 & 1.09 & 1.1 & 1.06 & 1.01 & 1.056 \\
\hline 2 & 0.83 & 0.96 & 1.02 & 1.02 & 0.9 & 0.98 & 0.91 & 0.92 & 0.87 & 0.934 \\
\hline 3 & 0.75 & 0.83 & 0.88 & 1.04 & 1.02 & 1.04 & 0.96 & 0.92 & 0.84 & 0.92 \\
\hline 4 & 0.8 & 0.77 & 0.85 & 0.91 & 0.92 & 0.98 & 0.91 & 0.94 & 0.88 & 0.884 \\
\hline 5 & 1.06 & 0.76 & 0.87 & 0.9 & 0.81 & 0.89 & 0.81 & 0.88 & 0.85 & 0.87 \\
\hline 6 & 0.7 & 0.4 & 0.47 & 0.49 & 0.41 & 0.47 & 0.4 & 0.44 & 0.41 & 0.466 \\
\hline Means & 0.89 & 0.833 & 0.894 & 0.939 & 0.884 & 0.934 & 0.883 & 0.893 & 0.85 & \\
\hline \multicolumn{11}{|c|}{ Second season $(2010-2011)$} \\
\hline 0 & 1.109 & 1.109 & 1.109 & 1.109 & 1.109 & 1.109 & 1.109 & 1.109 & 1.109 & 1.109 \\
\hline 1 & 0.853 & 0.81 & 0.853 & 0.939 & 0.853 & 0.917 & 0.789 & 0.874 & 0.96 & 0.872 \\
\hline 2 & 0.768 & 0.768 & 0.811 & 0.896 & 0.832 & 0.789 & 0.746 & 0.832 & 0.81 & 0.806 \\
\hline 3 & 0.682 & 0.725 & 0.747 & 0.789 & 0.747 & 0.768 & 0.725 & 0.768 & 0.811 & 0.751 \\
\hline 4 & 0.533 & 0.618 & 0.661 & 0.725 & 0.725 & 0.704 & 0.661 & 0.704 & 0.747 & 0.675 \\
\hline 5 & 0.405 & 0.512 & 0.576 & 0.64 & 0.661 & 0.618 & 0.597 & 0.597 & 0.704 & 0.59 \\
\hline 6 & 0.277 & 0.363 & 0.448 & 0.49 & 0.341 & 0.405 & 0.405 & 0.448 & 0.49 & 0.407 \\
\hline Means & 0.661 & 0.701 & 0.744 & 0.798 & 0.753 & 0.759 & 0.719 & 0.762 & 0.804 & \\
\hline \multicolumn{11}{|c|}{ LSD Values at $5 \%$ level } \\
\hline \multirow{2}{*}{\multicolumn{4}{|c|}{\begin{tabular}{|l|} 
Studied factors \\
Values, First season \\
\end{tabular}}} & \multicolumn{2}{|c|}{ Treat. } & \multicolumn{2}{|c|}{ St. Per } & \multicolumn{3}{|c|}{ Interaction } \\
\hline & & & & \multirow{2}{*}{\multicolumn{2}{|c|}{$\begin{array}{l}0.072 \\
0.043\end{array}$}} & \multirow{2}{*}{\multicolumn{2}{|c|}{$\begin{array}{l}0.064 \\
0.038\end{array}$}} & \multirow{2}{*}{\multicolumn{3}{|c|}{$\begin{array}{l}0.192 \\
0.114\end{array}$}} \\
\hline \multicolumn{4}{|c|}{ Values, Second season } & & & & & & & \\
\hline
\end{tabular}

Notes:- A= Imazalil, S= Salicylic acid 200 ppm, S2= Salicylic acid 300 ppm, K1= Chito-care 10000 ppm, K2= Chito-care 20000 ppm, Storage period by months.

Salicylic acid (As) can decrease respiration through inhibition of ethylene biosynthesis or action, lan addition it cause decrease respiration rate and reduce fruit weight losses by closing stoma. Our results also suggested that firmness caused by (SA) with inhibited activity of A Co. coating fruits with chito-care solutions can reduce respiration rate and ethylene production and increase internal $\mathrm{O}_{2}$ concentration it also interacts with the membrane of cells to alter cell permeability, in addition fruits become more firmer with less decayed. 
Table No (7):- Effect of Postharvest Treatments with Salicylic acid and Chito-care on V-C Contents of Navel Orange Fruits during cold storage.

\begin{tabular}{|c|c|c|c|c|c|c|c|c|c|c|}
\hline \multirow{2}{*}{$\begin{array}{l}\text { Storage } \\
\text { period }\end{array}$} & \multicolumn{10}{|c|}{ Postharvest treatments } \\
\hline & $\mathbf{A}$ & S1 & S2 & K1 & K2 & S2K2 & S1K1 & S1K2 & S2K1 & Means \\
\hline \multicolumn{11}{|c|}{ First season (2009-2010) } \\
\hline 0 & 64.4 & 64.43 & 64.43 & 64.43 & 64.43 & 64.43 & 64.43 & 64.43 & 64.43 & 64.43 \\
\hline 1 & 51.7 & 55.33 & 52 & 55 & 56.6 & 53 & 56 & 48.67 & 44.66 & 52.55 \\
\hline 2 & 47.5 & 50.93 & 45.33 & 43.73 & 49.33 & 45.07 & 49.6 & 47.2 & 47 & 47.3 \\
\hline 3 & 45.3 & 38.67 & 41.33 & 41 & 42.33 & 42 & 40.33 & 46.33 & 47.33 & 42.74 \\
\hline 4 & 33.8 & 34.67 & 33 & 35 & 34.33 & 34.67 & 35.33 & 36 & 38 & 34.98 \\
\hline 5 & 33.8 & 34.17 & 33.37 & 34.17 & 32.13 & 32.23 & 33.5 & 32.17 & 33.33 & 33.21 \\
\hline 6 & 30.1 & 30.9 & 33.8 & 31.9 & 31.5 & 31.17 & 30.3 & 31.07 & 30.66 & 31.27 \\
\hline Means & 43.8 & 44.16 & 43.32 & 43.6 & 44.38 & 43.22 & 44.21 & 43.7 & 43.63 & \\
\hline \multicolumn{11}{|c|}{ Second season (2010-2011) } \\
\hline 0 & 69.41 & 69.41 & 69.41 & 69.41 & 69.41 & 69.41 & 69.41 & 69.41 & 69.41 & 69.41 \\
\hline 1 & 49.13 & 46.85 & 51.42 & 49.14 & 50.54 & 44.57 & 47.99 & 43.42 & 49.73 & 48.09 \\
\hline 2 & 46.66 & 42.93 & 45.26 & 44.33 & 46.66 & 48.48 & 47.83 & 44.53 & 46.13 & 45.87 \\
\hline 3 & 39.74 & 45.56 & 45.14 & 42.12 & 44.8 & 43 & 43.73 & 43.06 & 42.66 & 43.31 \\
\hline 4 & 35.38 & 36.35 & 41.81 & 42.35 & 39.39 & 39.98 & 36.72 & 37 & 39.26 & 38.69 \\
\hline 5 & 30.44 & 29.33 & 34.66 & 39.55 & 37.77 & 39.21 & 34.33 & 31.23 & 38.1 & 34.96 \\
\hline 6 & 25.33 & 23.99 & 26.66 & 26.66 & 29.33 & 26.66 & 25.96 & 27.47 & 28.32 & 26.71 \\
\hline Means & 42.3 & 42.06 & 44.91 & 44.79 & 45.41 & 44.47 & 43.71 & 42.3 & 44.8 & \\
\hline \multicolumn{11}{|c|}{ LSD Values at $5 \%$ level } \\
\hline \multicolumn{4}{|c|}{ Studied factors } & \multicolumn{2}{|c|}{ Treat. } & \multicolumn{2}{|c|}{ St. Per } & \multicolumn{3}{|c|}{ Interaction } \\
\hline \multicolumn{4}{|c|}{ Values, First season } & \multicolumn{2}{|c|}{ N.S } & \multicolumn{2}{|c|}{0.916} & \multicolumn{3}{|c|}{ N.S } \\
\hline \multicolumn{4}{|c|}{ Values, Second season } & \multicolumn{2}{|c|}{2.316} & \multicolumn{2}{|c|}{2.042} & \multicolumn{3}{|c|}{ N.S } \\
\hline
\end{tabular}

Notes:- A= Imazalil, S= Salicylic acid 200 ppm, S2= Salicylic acid 300 ppm, K1= Chito-care 10000 ppm, K2= Chito-care 20000 ppm, Storage period by months.

Table No (8):- Effect of Postharvest Treatments with Salicylic acid and Chito-care on Total Sugar Contents of Navel Orange Fruits during cold storage.

\begin{tabular}{|c|c|c|c|c|c|c|c|c|c|c|}
\hline \multirow{2}{*}{$\begin{array}{c}\text { Storage } \\
\text { period }\end{array}$} & \multicolumn{10}{|c|}{ Postharvest treatments } \\
\hline & $\mathbf{A}$ & S1 & S2 & K1 & K2 & S2K2 & S1K1 & S1K2 & S2K1 & Means \\
\hline \multicolumn{11}{|c|}{ First season } \\
\hline 0 & 8.11 & 8.11 & 8.11 & 8.11 & 8.11 & 8.11 & 8.11 & 8.11 & 8.11 & 8.11 \\
\hline 1 & 9.01 & 8.88 & 9.36 & 8.96 & 9.22 & 8.90 & 8.69 & 8.80 & 9.58 & 9.04 \\
\hline 2 & 9.86 & 9.30 & 9.44 & 9.66 & 9.30 & 9.60 & 9.33 & 9.46 & 10.06 & 9.56 \\
\hline 3 & 9.86 & 9.62 & 9.73 & 9.78 & 9.17 & 9.73 & 9.88 & 9.70 & 10.14 & 9.73 \\
\hline 4 & 9.88 & 9.76 & 9.89 & 10.02 & 9.49 & 10.00 & 10.04 & 9.92 & 10.65 & 9.96 \\
\hline 5 & 9.70 & 9.97 & 10.16 & 10.13 & 9.54 & 10.16 & 9.86 & 9.62 & 10.77 & 9.99 \\
\hline 6 & 9.46 & 9.70 & 10.02 & 10.26 & 10.26 & 9.78 & 9.70 & 10.18 & 10.26 & 9.96 \\
\hline Means & 9.41 & 9.33 & 9.53 & 9.56 & 9.30 & 9.47 & 9.37 & 9.40 & 9.94 & ---- \\
\hline \multicolumn{11}{|c|}{ Second season (2010-2011) } \\
\hline 0 & 8.63 & 8.63 & 8.63 & 8.63 & 8.63 & 8.63 & 8.63 & 8.63 & 8.63 & 8.63 \\
\hline 1 & 10.14 & 9.57 & 9.15 & 8.81 & 9.72 & 8.98 & 9.25 & 9.12 & 9.21 & 9.328 \\
\hline 2 & 10.45 & 10.54 & 10.3 & 9.49 & 10.22 & 9.97 & 9.69 & 9.57 & 10.17 & 10.04 \\
\hline 3 & 10.68 & 10.88 & 10.65 & 10.37 & 10.28 & 10.51 & 10.48 & 10.65 & 10.4 & 10.54 \\
\hline 4 & 10.25 & 10.65 & 10.93 & 10.88 & 10.71 & 10.36 & 10.45 & 9.66 & 10.59 & 10.5 \\
\hline 5 & 9.49 & 9.86 & 10.05 & 9.69 & 9.43 & 9.52 & 9.26 & 9.32 & 9.55 & 9.574 \\
\hline 6 & 8.64 & 9.35 & 9.57 & 9.57 & 9.01 & 8.95 & 8.75 & 8.69 & 8.95 & 9.053 \\
\hline Means & 9.754 & 9.926 & 9.897 & 9.634 & 9.714 & 9.56 & 9.501 & 9.377 & 9.643 & \\
\hline \multicolumn{11}{|c|}{ LSD Values at 5\% level } \\
\hline \multicolumn{4}{|c|}{ Studied factors } & \multicolumn{2}{|c|}{ Treat. } & \multicolumn{2}{|c|}{ St. Per } & \multicolumn{3}{|c|}{ Interaction } \\
\hline \multicolumn{4}{|c|}{ Values, First season } & \multicolumn{2}{|c|}{0.089} & \multicolumn{2}{|c|}{0.078} & \multicolumn{3}{|c|}{0.234} \\
\hline \multicolumn{4}{|c|}{ Values, Second season } & \multicolumn{2}{|c|}{0.099} & \multicolumn{2}{|c|}{0.087} & \multicolumn{3}{|c|}{0.261} \\
\hline
\end{tabular}

Notes:- A= Imazalil, S= Salicylic acid 200 ppm, S2= Salicylic acid 300 ppm, K1= Chito-care 10000 ppm, K2= Chito-care 20000 ppm, Storage period by months. 


\section{REFERENCES}

A.O.A.C. (1990). Association of Official Analytical Agriculture Chemists Official Methods of Analysis, $14^{\text {th }}$ ed. Washington, USA.

Abd El-Hafeez, A. A. (1998). Physiological studies on the handling and storage of Navel orange. Ph.D. Thesis in Pomology, Fac. Agric., Al Azhar Univ., A.R.E.

Barakat, M. R.; M. A. A. Mohamed; M. A. Essa and Z.A. Zaki, (2012). Effect of Using Some Biological Post Harvest Treatments on Storability of Washington Navel Orange Fruits Compared with Imazalil Post Harvest Chemical Treatments. Journal of Horticultural Science \& Ornamental Plants, 4(1): 50-57.

Chien, P. J.; F. Sheu and H. R. Lin (2007). Coating citrus (Murcott tangor) fruit with low molecular weight chitosan increases postharvest quality and shelf life. Food Chemistry, 100:1160-1164.

Du, J.; H. Gemma and S. Iwahori (1997). Effects of Chitosan Coating on the Storage of Peach, Japanese Pear, and Kiwifruit. Journal of the Japanese Society for Horticultural Science, 66(1):15-22.

Johnson, G. I. and S. Sangchote (1994). Control of postharvest diseases of tropical fruits: challenges for the 21st century. In: Champ, B.R., Highley, E., Johnson, G.I. (Eds.), Postharvest Handling of Tropical Fruits. Australian Center for International Agricultural Research, Canberra, pp. 140-167.

Kazemi, M.; M. Aran and S. Zamani (2011). Effect of Salicylic Acid Treatments on Quality Characteristics of Apple Fruits During Storage. American Journal of Plant Physiology, 6:113-119.

Kittur, F. S.; K. R. Kumar and R.N. Tharanathan (2001). Functional packaging of chitosan films. Z. Tebensmittelunterssuchung undforshung A 206:44-47.

Li, L. P. and T. Han (1999). The effects of salicylic acid in the storage of peach. Food Sci., 7: 61-63.

Lucas, G. H. (1944). Determining ascorbic acid in large number of plant samples. Ind. Eng. Chem. and Ed.,16:649-652.

McGuire, R. G. (1992). Reporting of objective colour measurements. Hort. Sci., 27(12):1254-1255.

Ministry of Agriculture and land reclamation, Economic affairs sector, Bulletin of the agricultural statistics Part (2) Summer \& Neil crops, 2009/2010 published in October 2011.

Romanazzi, G. ; F. Nigro; A. Ippolito; D. DiVenere and M. Salerno, (2002). Effects of Pre- and Postharvest Chitosan Treatments to Control Storage Grey Mold of Table Grapes. Journal of Food Science, 67(5):1862-1867.

Snedecor, G. W. and W. G. Cochran (1980). Statistical methods. 7th edition lowa State Univ. Press Ames., lowa, U.S.A. p. 593. 
Solaimani, M.; Y. Mostofi; A. Motallebiazar, F. J. Moghadam and M. Ghasemnezhad (2009). Effects of MESA vapor treatment on the postharvest quality of Hayward kiwifruit. Proceedings of the $6^{\text {th }}$ International Postharvest Symposium, Turkey.

Srivastava, M. K. and U. N. Dwivedi (2000). Delayed ripening of banana fruit by salicylic acid. Plant Sci., 158:87-96.

Tareen, M. J.; N. A. Abbasi and S. Hafeez (2012). Effect of salicylic acid treatments on storage life of Peach fruits cv. 'flordaking'. Pak. J. Bot., 44(1):119-124.

Wang, J.; B. Wang; W. Jiang and Y. Zhao (2007). Quality and Shelf Life of Mango (Mangifera Indica L. cv. 'Tainong') Coated by Using Chitosan and Polyphenols. Food Science and Technology International, 13(4): 317-322.

Wang, L.; S. Chena; W. Kong; S. Li and D. D. Archbold (2006). Salicylic acid pretreatment alleviates chilling injury and affects the antioxidant system and heat shock proteins of peaches during cold storage. Postharvest Biol. and Technol., 41:244-251.

Yan, T.; Q. G. Shen and C. D. Liu (1998). Effects of salicylic acid (SA) on ripening fruits. Chinese Bulletin of Bot., 15:61-64.

Yao, $\mathrm{H}$. and S. Tian (2005). Effects of pre- and post-harvest application of salicylic acid or methyl jasmonate on inducing disease resistance of sweet cherry fruit in storage. Postharvest Biology and Technology, 35:253-262.

Zhou, R.; Y. Mo; Y. Li; Y. Zhao; G. Zhang and Y. Hu (2008). Quality and internal characteristics of Huanghua pears (Pyrus pyrifolia Nakai, cv. Huanghua) treated with different kinds of coatings during storage. Postharvest Biology and Technology, 49:171-179.

Zhu, X.; Q. Wang; G. Cao and W. Jiang (2008). Effects Of Chitosan Coating On Postharvest Quality Of Mango (Mangifera Indica L. Cv. Tainong) Fruits. Journal of Food Processing and Preservation, 32(5):1745-4549. 
Mohamed, M. A. A. et al.

تـأثير المعاملـه بحمـض السالسـيليك و الثـيتوكار بعـد الحصـاد علـي جـودة ثمـار

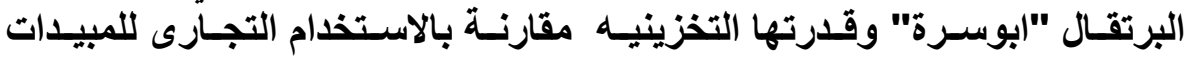
الفطريه

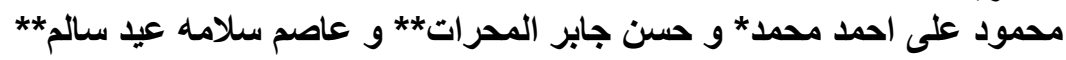

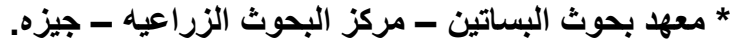

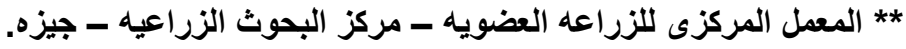

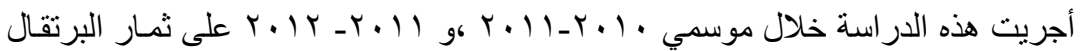

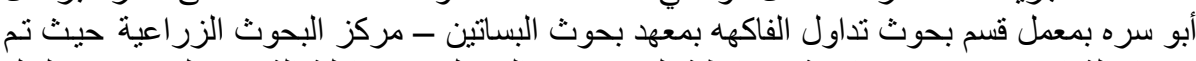

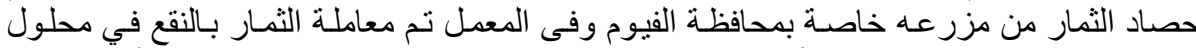

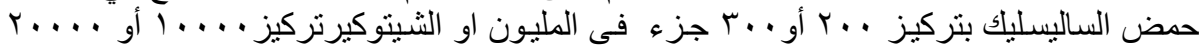

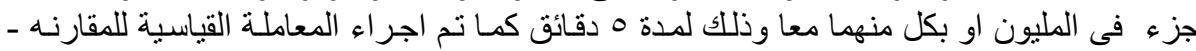

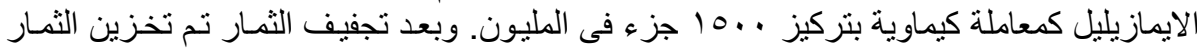

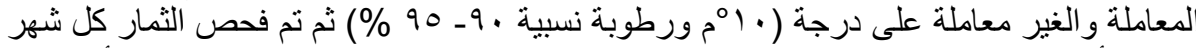

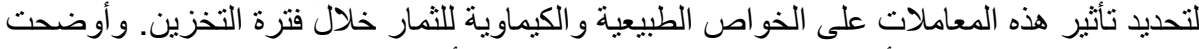

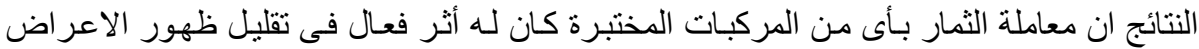

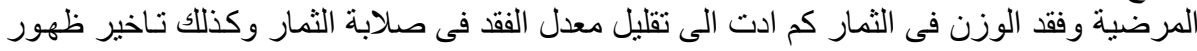

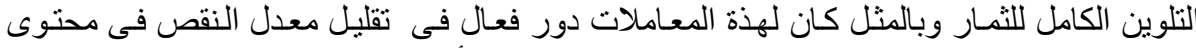

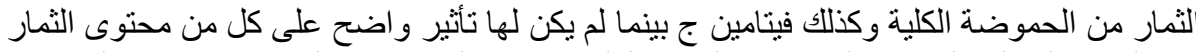

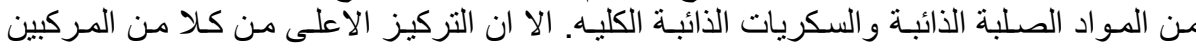

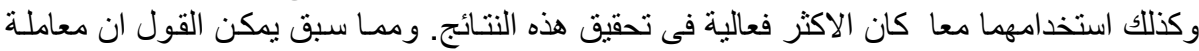

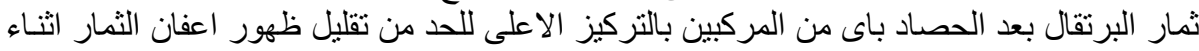

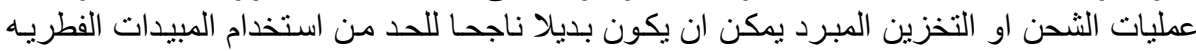

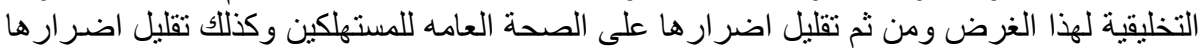
على البيئه.

كلية الزراعة - جامعة المنصورة مركز البحوث الزراعية
قام بتحكيم البحث

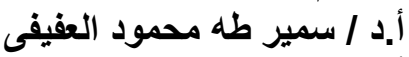

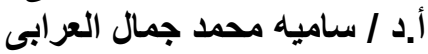

